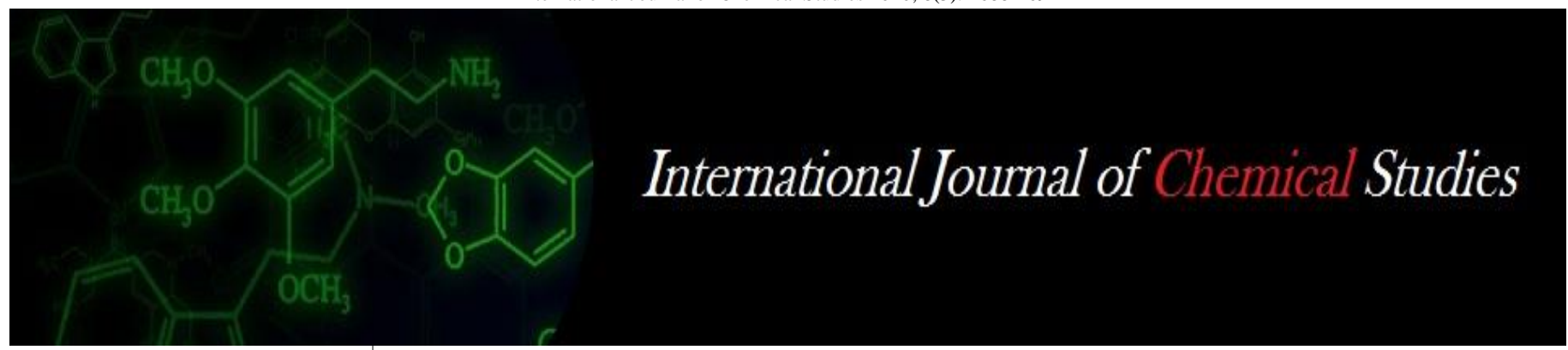

P-ISSN: 2349-8528

E-ISSN: 2321-4902

www.chemijournal.com

IJCS 2020; 8(3): 2688-2692

(C) 2020 IJCS

Received: 08-03-2020

Accepted: 10-04-2020

\section{KK Ajmal}

Department of Agronomy,

College of Agriculture, Professor

Jayashankar Telangana State

Agricultural University,

Rajendranagar, Hyderabad,

Telangana, India

\section{Goverdhan}

AICRP-Integrated Farming Systems Professor Jayashankar Telangana State Agricultural University, Rajendranagar,

Hyderabad, Telangana, India

\section{S Sridevi}

AICRP-Integrated Farming

Systems Professor Jayashankar

Telangana State Agricultural

University, Rajendranagar,

Hyderabad, Telangana, India

\section{K Suresh}

AICRP-Integrated Farming

Systems Professor Jayashankar

Telangana State Agricultural

University, Rajendranagar,

Hyderabad, Telangana, Indi
Corresponding Author:

KK Ajmal

Department of Agronomy,

College of Agriculture, Professor

Jayashankar Telangana State

Agricultural University,

Rajendranagar, Hyderabad,

Telangana, India

\section{Growth and dry matter production of semidry rice under varied doses and time of nitrogen application}

\author{
KK Ajmal, M Goverdhan, S Sridevi and K Suresh
}

DOI: https://doi.org/10.22271/chemi.2020.v8.i3am.9618

\begin{abstract}
An experiment was conducted during kharif season of 2017 on clay loam soils of Agricultural Research Institute, PJTSAU, Rajendranagar with an aim to find out the optimum dose and time of nitrogen application for semi-dry rice. Observations were recorded at 20 day interval from sowing viz., 20, 4060 and 80 DAS and at harvest. At all the times of sampling growth parameters like seedling vigour index, plant height, number of tillers $\mathrm{m}^{-2}$, dry matter production, leaf area index were recorded to be highest with application of $160 \mathrm{~kg} \mathrm{~N} \mathrm{ha}^{-1} 25 \%$ each at sowing, 20 DAS, 40 DAS and 60 DAS compared to the other treatments. However, growth recorded with $160 \mathrm{~kg}$ in four equal splits was found to be on par with the growth in the treatments having 160 and $140 \mathrm{~kg} \mathrm{~N} \mathrm{ha}^{-1}$ applied at various splits and with application of $120 \mathrm{~kg} \mathrm{~N} \mathrm{ha}^{-1} \mathrm{~N}$ in 4 equal splits at sowing, 20, 40 and 60 DAS. Observations on growth parameters were found to be the lowest with application with of nitrogen at $120 \mathrm{~kg} \mathrm{ha}^{-1} \mathrm{~N}$ in 3 splits with $12 \%$ at sowing, $44 \%$ at 40 DAS and $44 \%$ at 60 DAS (farmer's practice).
\end{abstract}

Keywords: Rice, semi-dry system, time and dose of nitrogen application

\section{Introduction}

The total area of rice in world is $163.3 \mathrm{~m}$ ha with production of $749.7 \mathrm{mt}$ (FAO 2016) ${ }^{[5]}$. The total area of rice in India is $44.50 \mathrm{~m}$ ha, with a production and productivity of $108.8 \mathrm{mt}$ and 2.38 t ha-1 respectively (Directorate of Economics and Statistics, 2015-16). Telangana State contributes to $2.09 \mathrm{~m}$ ha area with a production of $6.62 \mathrm{mt}$, at an average productivity of 3295 $\mathrm{kg}$ ha-1 (Season and Crop report Telangana, 2016-17). Semi dry system, is a method of cultivation of rice wherein seeds are sown in ploughed dry soil with monsoon rains same as aerobic rice and when the monsoon become active the field is impounded in with rainwater or canal water of a project or bore water and continued as wet land crop. It is most common in the project areas where the release of project water is not in time there by transplantation is not being done well in time. They cut down the initial water consumption $30 \%$ by avoiding rising of seedlings in nursery, puddling, and transplanting under puddled soil. Semi dry system reduces the cost of cultivation by omitting the preparatory operation like puddling, levelling, bund formation and transplantation. It constitutes of $17.53 \mathrm{~m}$ ha area with $36.48 \%$ production in our country. In view fast development of irrigation facilities this system is likely to gain lot of importance in the state of Telangana. There is every need to develop complete production technology for semi dry system in project ayacut areas and bore well irrigated system having sufficient water. Fertilizer is the most important factor deciding the growth and productivity of rice. Among different nutrients nitrogen $(\mathrm{N})$ is the most limiting nutrient for rice production and is required more consistently and in larger amounts than other nutrients. Hence an attempt was made in this study to find out the optimum dose and time of nitrogen application to rice under semi-dry system.

\section{Material and methods}

The study was conducted with ten treatments and laid out in randomized block design with three replications. The treatments comprised of three doses of nitrogen $(120,140$ and $160 \mathrm{~kg}$ ha-1) and three schedules of nitrogen application (25\% each at sowing, 20 DAS, 40 DAS and 60 DAS, $20 \%$ at sowing, $20 \%$ at 20 DAS, $30 \%$ at 40 DAS and 30 at 60 DAS, $10 \%$ at sowing, 
$10 \%$ at 20 DAS, $40 \%$ at $40 \mathrm{DAS}$ and $40 \%$ at $60 \mathrm{DAS}$.) and were evaluated against the farmers practice $(120 \mathrm{~kg}$ ha- $1 \mathrm{~N}$ at 3 splits with $12 \%$ at sowing, $44 \%$ at 40 DAS and $44 \%$ at 60 DAS). The soil of the experimental site was clay loam in texture, slightly alkaline in reaction, non saline, low in organic carbon and available nitrogen, high in available phosphorous and potassium. The crop was sown in non puddle field by giving one pre sowing irrigation and grown as irrigated dry crop up to 40 DAS and there after converted to wet and $2-5 \mathrm{~cm}$ standing water was maintained up to the harvesting stage of the crop. Conversion to wet at 40 DAS done with an assumption that canal water will be available by that time for cultivation of rice. The water was withdrawn 10 days before harvesting. In this study a short duration (120 days) variety JGL-18047 (Bathukamma) was used. Different doses nitrogen $(120,140$ and $160 \mathrm{~kg}$ ha-1), in the form of urea was applied in accordance to treatment specification in the four splits. Phosphorous @ 60 kg ha-1 in the form of SSP and potassium @ $40 \mathrm{~kg} \mathrm{ha}-1$ in the form of MOP were applied at the time of sowing as basal. The growth of the crop expressed as seedling vigour index, plant height, tiller production, leaf area index and dry matter accumulation of semidry rice at different stages as influenced by dose and time of application of nitrogen is presented this paper.

\section{Results and discussion Seedling vigour}

Seedling vigour is the ability of plant to emerge rapidly from soil or water. It helps in better plant establishment and successful competition with weeds in all phases of seedling development from seed germination through to stand establishment. Seedling vigour was expressed as seedling vigour index (SVI). It was recorded at 15 DAS, 30 DAS, and 45 DAS in semidry rice (Table 1 ) by recording the shoot length, root length and germination percentage. The average of the shoot length and root length were worked out and SVI was worked out using the following formula
$\mathrm{SVI}=\frac{\text { Seedling length }(\text { root }+ \text { shoot }) \times \text { Germination percentage }}{100}$

At 15 DAS, highest seedling vigour index (27.19) was recorded with application of nitrogen @ $160 \mathrm{~kg}$ ha- 1 in 4 equal splits of $25 \%$ each at sowing, 20, 40 and 60 DAS compared to the other treatments. However the seedling vigour recorded in various treatments with $120 \mathrm{~kg} \mathrm{~N}$ ha-1 (T1 to T4) and $140 \mathrm{~kg} \mathrm{~N}$ ha-1 (T5 to T7) were found to be on par with higher doses of $\mathrm{N}$ (160 kg ha-1). This might be due to the fact under direct seeded rice, initial growth is very slow and root system is not well developed and plants fail to absorb the applied nitrogen, thus relatively higher losses through leaching/ denitrification are expected (Thindet al. 2018) ${ }^{[10]}$. At 30 and 45 DAS, the same T8 treatment (application of 160 $\mathrm{kg} \mathrm{N}$ ha- 1 in 4 equal splits of $25 \%$ each in 4 equal splits at sowing, 20, 40 and 60 DAS) continued to register the highest seedling vigour index (42.72 and 56.13 respectively) compared to the other treatments.

However, this was found to be on par with the other lower doses of nitrogen viz., 120 and $140 \mathrm{~kg} \mathrm{~N}$ ha-1 when they were applied in four equal splits of 25\% each at sowing, 20, 40 and 60 DAS (T2 and T5). Lowest seedling vigour index (34.20 and 46.32 respectively) was noticed in the farmer's practice treatment (T1- application of nitrogen at $120 \mathrm{~kg}$ ha- $1 \mathrm{~N}$ in 3 splits with $12 \%$ at sowing, $44 \%$ at 40 DAS and $44 \%$ at 60 DAS) and was significantly lower than all the doses (120, 140 and $160 \mathrm{~kg} \mathrm{~N}$ ha-1) when applied as $25 \%$ each in 4 equal splits of at sowing, 20, 40 and 60 DAS (T2, T5, and T8) and all the doses ( 140 and $160 \mathrm{~kg} \mathrm{~N}$ ha-1) when applied as $20 \%$ at sowing, $20 \%$ at $20 \mathrm{DAS}, 30 \%$ at $40 \mathrm{DAS}$ and $30 \%$ at 60 DAS. Application of higher doses of nitrogen enhanced the growth of meristamatic and vegetative tissues and in turn influenced both the shoot length and root length. Application of nitrogen in equal split doses increased the shoot and root growth significantly due to availability of sufficient quantities throughout the crop growth stages when compared to the other unequal split applications of nitrogen.

Table 1: Seedling vigour of semi dry rice as influenced by dose and time of nitrogen application

\begin{tabular}{|c|c|c|c|c|c|c|c|c|c|c|c|}
\hline \multirow{3}{*}{ Trt. } & \multirow{3}{*}{ Treatments } & \multicolumn{10}{|c|}{ Seedling vigour } \\
\hline & & \multicolumn{3}{|c|}{15 DAS } & \multicolumn{4}{|c|}{ 30 DAS } & \multicolumn{3}{|c|}{45 DAS } \\
\hline & & \begin{tabular}{c|} 
Germi- \\
nation $(\%)$
\end{tabular} & \begin{tabular}{|c|} 
Shoot \\
growth
\end{tabular} & $\begin{array}{c}\text { Root } \\
\text { growth }\end{array}$ & SVI & \begin{tabular}{|c|} 
Shoot \\
growth
\end{tabular} & \begin{tabular}{c|} 
Root \\
growth
\end{tabular} & SVI & \begin{tabular}{|c|} 
Shoot \\
growth
\end{tabular} & \begin{tabular}{|c|} 
Root \\
growth
\end{tabular} & SVI \\
\hline $\mathrm{T} 1$ & $\begin{array}{l}\text { Farmer's practice (120 kg ha- } 1 \mathrm{~N} \text { in } 3 \text { splits of } 12 \% \text { at sowing, } 44 \% \text { at } \\
40 \text { DAS and } 44 \% \text { at } 60 \text { DAS) }\end{array}$ & 90 & 18.51 & 7.56 & 23.46 & 25.40 & 13.21 & 34.75 & 32.51 & 18.96 & 46.32 \\
\hline $\mathrm{T} 2$ & $\begin{array}{c}120 \mathrm{~kg} \text { ha- } 1 \mathrm{~N} \text { in } 4 \text { equal splits of } 25 \% \text { each at sowing, } 20,40 \text { and } 60 \\
\text { DAS }\end{array}$ & 90 & 19.21 & 10.26 & 26.52 & 28.82 & 15.40 & 39.80 & 36.83 & 21.71 & 52.69 \\
\hline $\mathrm{T} 3$ & $\begin{array}{c}120 \mathrm{~kg} \text { ha- } 1 \mathrm{~N} \text { in } 4 \text { splits of } 10 \% \text { at sowing, } 10 \% \text { at } 20 \mathrm{DAS}, 40 \% \text { at } \\
40 \text { DAS and } 40 \% \text { at } 60 \text { DAS. }\end{array}$ & 90 & 18.2 & 7.06 & 22.73 & 26.81 & 15.41 & 36.93 & 34.50 & 20.46 & 49.47 \\
\hline $\mathrm{T} 4$ & $\begin{array}{c}120 \mathrm{~kg} \text { ha- } 1 \mathrm{~N} \text { in } 4 \text { splits of } 20 \% \text { at sowing, } 20 \% \text { at } 20 \mathrm{DAS}, 30 \% \text { at } \\
40 \text { DAS and } 30 \% \text { at } 60 \text { DAS }\end{array}$ & 90 & 18.91 & 8.06 & 24.27 & 27.30 & 15.33 & 38.37 & 35.81 & 21.00 & 51.13 \\
\hline T5 & $\begin{array}{c}140 \mathrm{~kg} \text { ha- } 1 \mathrm{~N} \text { in } 4 \text { equal splits of } 25 \% \text { each at sowing, } 20,40 \text { and } 60 \\
\text { DAS }\end{array}$ & 90 & 21.50 & 8.21 & 26.76 & 29.72 & 16.11 & 41.25 & 38.63 & 22.13 & 54.69 \\
\hline T6 & $\begin{array}{c}140 \mathrm{~kg} \text { ha- } 1 \mathrm{~N} \text { in } 4 \text { splits of } 10 \% \text { at sowing, } 10 \% \text { at } 20 \mathrm{DAS}, 40 \% \text { at } \\
40 \text { DAS and } 40 \% \text { at } 60 \text { DAS }\end{array}$ & 90 & 18.30 & 7.32 & 23.06 & 27.10 & 14.42 & 37.37 & 35.95 & 20.43 & 50.75 \\
\hline $\mathrm{T} 7$ & $\begin{array}{c}140 \mathrm{~kg} \text { ha- } 1 \mathrm{~N} \text { in } 4 \text { splits of } 20 \% \text { at sowing, } 20 \% \text { at } 20 \mathrm{DAS}, 30 \% \text { at } \\
40 \mathrm{DAS} \text { and } 30 \% \text { at } 60 \mathrm{DAS}\end{array}$ & 90 & 19.82 & 9.01 & 25.95 & 28.2 & 15.38 & 39.06 & 36.20 & 20.56 & 51.09 \\
\hline $\mathrm{T} 8$ & $\begin{array}{c}160 \mathrm{~kg} \text { ha- } 1 \mathrm{~N} \text { in } 4 \text { equal splits of } 25 \% \text { each at sowing, } 20,40 \text { and } 60 \\
\text { DAS }\end{array}$ & 90 & 21.90 & 8.31 & 27.19 & 31.33 & 16.13 & 42.72 & 40.12 & 22.25 & 56.14 \\
\hline T9 & $\begin{array}{c}160 \mathrm{~kg} \text { ha- } 1 \mathrm{~N} \text { in } 4 \text { splits of } 10 \% \text { at sowing, } 10 \% \text { at } 20 \mathrm{DAS}, 40 \% \text { at } \\
40 \text { DAS and } 40 \% \text { at } 60 \text { DAS }\end{array}$ & 90 & 18.52 & 8.19 & 24.04 & 27.50 & 14.70 & 37.98 & 36.23 & 20.90 & 51.42 \\
\hline \multirow[t]{4}{*}{$\mathrm{T} 10$} & $\begin{array}{c}160 \mathrm{~kg} \text { ha- } 1 \mathrm{~N} \text { in } 4 \text { splits of } 20 \% \text { at sowing, } 20 \text { at } 20 \mathrm{DAS}, 30 \% \text { at } 40 \\
\text { DAS and } 30 \% \text { at } 60 \text { DAS }\end{array}$ & 90 & 20.84 & 8.95 & 26.81 & 30.52 & 15.92 & 41.80 & 39.11 & 21.32 & 54.39 \\
\hline & $\mathrm{SE}(\mathrm{m}) \pm$ & & & & 1.18 & & & 1.43 & & & 1.76 \\
\hline & $\mathrm{CD}(\mathrm{p}=0.05)$ & & & & NS & & & 4.30 & & & 5.28 \\
\hline & $\mathrm{CV}(\%)$ & & & & 8.2 & & & 6.4 & & & 6.6 \\
\hline
\end{tabular}




\section{Plant height (cm)}

Plant height is an important agronomic trait that directly affects the yield of rice crop. They are directly associated with the vegetative growth and dry matter production. If Plants are too short; it will lead to insufficient growth and ultimately affect the yield potential of rice. They are governed by many factors such as light space, water and nutrients. In this study plant height was recorded at $20 \mathrm{DAS}, 40 \mathrm{DAS}, 60 \mathrm{DAS}, 80$ DAS and harvest in this study and presented in table 2. Plant height increased progressively from the seedling to the panicle initiation, there after the growth was slow and increase in height was less. Among the different doses of nitrogen the highest plant height was recorded with $160 \mathrm{~kg} \mathrm{~N}$ ha- 1 compared to the other two doses (120 and $140 \mathrm{~kg} \mathrm{~N}$ ha1) of nitrogen at all crop growth stages/ days after sowing, but it was found to be influenced by the time and quantity of fertilizer applied in splits. With regard to time of application of $\mathrm{N}$, the highest plant height was noticed in all the growth stages in treatments with application of $\mathrm{N}$ in 4 equal splits at sowing, 20, 40 and 60 DAS than the other splits and application of $120 \mathrm{~kg} \mathrm{~N}$ ha-1 was found to be equally effective in promoting the crop growth as that of higher doses, as sufficient quantities of nitrogen was available for the plant from the seedling stage. This might be due to the fact that nitrogen is directly associated with plant metabolism and vegetative growth. Application of excess nitrogen to the plant results in increased vegetative growth due to meristamatic growth, cell division and cell elongation (Rani, 2012 and Amrutha, 2014) ${ }^{9,2]}$. The results collaborate with findings of Bai et al. (2014) ${ }^{[3]}$ and Hebbal (2015) ${ }^{[6]}$. Lowest plant height at all the growth stages was observed in farmer's practice.

\section{Tiller production}

Tillering ability is one of the most important traits of rice, since it can have a significant influence on the future production of panicles and as a consequence affects on grain yield (Miller et al., 1991) ${ }^{[8]}$. They also contributes to the dry matter production there by the straw yield will increase significantly. Tiller production (number of tillers $\mathrm{m}-2$ ) was recorded at $20 \mathrm{DAS}, 40 \mathrm{DAS}, 60 \mathrm{DAS}, 80 \mathrm{DAS}$ and harvest (Table 2). At 20 DAS the tillers production was not initiated. Hence all the treatments irrespective of dose and time of application of nitrogen found were to be on par. At 40, 60 and 80 DAS, application of nitrogen @ $160 \mathrm{~kg} \mathrm{ha}-1$ in 4 equal splits i.e., at sowing, 20, 40 and 60 DAS had recorded the highest tillers m-2 (344, 424 and 459 respectively) which were found to be on par with the treatments having 160 and $140 \mathrm{~kg} \mathrm{~N}$ ha-1 applied at various splits and T2 (application of $120 \mathrm{~kg} \mathrm{~N}$ ha- $1 \mathrm{~N}$ in 4 equal splits at sowing, 20, 40 and 60 DAS). Lowest tillers $\mathrm{m}-2$ was noticed in the farmer's practice (260, 320 and 348) which was significantly inferior with the all the different splits application of the 140 and $160 \mathrm{~kg} \mathrm{~N}$ ha 1 and T2- application of nitrogen @ $120 \mathrm{~kg}$ ha- 1 in 4 equal splits i.e., at sowing, 20, 40 and 60 DAS.

At harvest number of tillers $\mathrm{m}-2$ was reduced compared to the previous growth stages due to the decaying of unproductive tillers from the plots. However, treatment T8- application of nitrogen @ $160 \mathrm{~kg}$ ha-1 in 4 equal splits i.e., at sowing, 20, 40 and 60 DAS was found to record the highest tillers m-2 (381) compared to the other treatments which was found to be on par with the treatments having 160 and $140 \mathrm{~kg} \mathrm{~N}$ ha- 1 applied at various splits and T2 (application of $120 \mathrm{~kg} \mathrm{~N}$ ha- $1 \mathrm{~N}$ in 4 equal splits at sowing, 20, 40 and 60 DAS). Lowest number of tillers m-2 was noticed in the farmer's practices (287) which was significantly inferior with the all the different splits application of the 140 and $160 \mathrm{~kg} \mathrm{~N}$ ha-1 and T2- application of nitrogen @ $120 \mathrm{~kg}$ ha-1 in 4 equal splits i.e., at sowing, 20, 40 and 60 DAS and on par with T3 (120 kg N ha-1 with $10 \%$ at sowing, $10 \%$ at $20 \mathrm{DAS}, 40 \%$ at $40 \mathrm{DAS}$ and $40 \%$ at 60 DAS) and T4 (120 kg N ha-1 in 4 splits of $20 \%$ at sowing, $20 \%$ at 20 DAS, $30 \%$ at 40 DAS and $30 \%$ at 60 DAS). The results corroborate with results of Hebbal (2015) ${ }^{[6]}$ and Bai et al. $(2014)^{[3]}$.

Table 2: Leaf area index and Dry matter production of semi dry rice as influenced by dose and time of nitrogen application

\begin{tabular}{|c|c|c|c|c|c|c|c|c|c|c|c|}
\hline \multirow{3}{*}{$\begin{array}{l}\text { Trt. } \\
\text { No }\end{array}$} & \multirow{3}{*}{ Treatment } & \multicolumn{5}{|c|}{ Plant height $(\mathbf{c m})$} & \multicolumn{5}{|c|}{ Number of tillers m-2 } \\
\hline & & \multirow{3}{*}{$\begin{array}{c}\begin{array}{c}\mathbf{2 0} \\
\text { DAS }\end{array} \\
19.6\end{array}$} & \multirow{2}{*}{$\begin{array}{c}40 \\
\text { DASI }\end{array}$} & \multirow{2}{*}{\multicolumn{2}{|c|}{\begin{tabular}{|c|c|}
60 & 80 \\
DAS & DASS \\
\end{tabular}}} & \multirow{2}{*}{ Harves } & \multirow{2}{*}{$\begin{array}{c}20 \\
\text { DAS }\end{array}$} & \multirow{2}{*}{\begin{tabular}{c|c}
40 \\
DAS
\end{tabular}} & \multirow{2}{*}{ 60 } & \multirow{2}{*}{\begin{tabular}{c|c} 
80 \\
DAS
\end{tabular}} & \multirow{2}{*}{ Harvest } \\
\hline & & & & & & & & & & & \\
\hline $\mathrm{T} 1$ & $\begin{array}{c}\text { Farmer's practice (120 kg ha- } 1 \mathrm{~N} \text { in } 3 \text { splits of } 12 \% \text { at sowing, } 44 \% \text { at } 40 \text { DAS and } 44 \% \text { at } 60 \\
\text { DAS) }\end{array}$ & & 29.9 & 47.9 & 66.4 & 69.2 & 121.3 & 260.0 & 320.0 & 348.0 & 286.6 \\
\hline $\mathrm{T} 2$ & $120 \mathrm{~kg}$ ha- $1 \mathrm{~N}$ in 4 equal splits of $25 \%$ each at sowing, 20, 40 and $60 \mathrm{DAS}$ & 20.6 & 34.1 & 56.3 & 76.9 & 79.4 & 124.0 & 308.7 & 375.3 & 416.0 & 350.6 \\
\hline T3 & $\begin{array}{l}120 \mathrm{~kg} \text { ha- } 1 \mathrm{~N} \text { in } 4 \text { splits of } 10 \% \text { at sowing, } 10 \% \text { at } 20 \mathrm{DAS}, 40 \% \text { at } 40 \mathrm{DAS} \text { and } 40 \% \text { at } 60 \\
\text { DAS. }\end{array}$ & 19.4 & 30.5 & 52.9 & 72.7 & 75.4 & 122.7 & 276.0 & 340.0 & 366.6 & 313.3 \\
\hline $\mathrm{T} 4$ & $\begin{array}{l}120 \mathrm{~kg} \text { ha- } 1 \mathrm{~N} \text { in } 4 \text { splits of } 20 \% \text { at sowing, } 20 \% \text { at } 20 \mathrm{DAS}, 30 \% \text { at } 40 \mathrm{DAS} \text { and } 30 \% \text { at } 60 \\
\text { DAS }\end{array}$ & 20.2 & 32.3 & 53.8 & 74.3 & 76 & 128.7 & 298.6 & & 393.3 & 330.6 \\
\hline T5 & $140 \mathrm{~kg}$ ha- $1 \mathrm{~N}$ in 4 equal splits of $25 \%$ each at sowing, 20,40 and $60 \mathrm{DAS}$ & 22.2 & 35.6 & 58.5 & 80.0 & 83.2 & 132.0 & 329.3 & 400.6 & 442.6 & 358.6 \\
\hline T6 & $\begin{array}{c}140 \mathrm{~kg} \text { ha- } 1 \mathrm{~N} \text { in } 4 \text { splits of } 10 \% \text { at sowing, } 10 \% \text { at } 20 \mathrm{DAS}, 40 \% \text { at } 40 \mathrm{DAS} \text { and } 40 \% \text { at } 60 \\
\text { DAS }\end{array}$ & 19.5 & 32.5 & 55.4 & 75.7 & 78.3 & 126.6 & 286.6 & 372.3 & 412.6 & 337.3 \\
\hline $\mathrm{T} 7$ & $\begin{array}{l}140 \mathrm{~kg} \text { ha- } 1 \mathrm{~N} \text { in } 4 \text { splits of } 20 \% \text { at sowing, } 20 \% \text { at } 20 \mathrm{DAS}, 30 \% \text { at } 40 \mathrm{DAS} \text { and } 30 \% \text { at } 60 \\
\text { DAS }\end{array}$ & 21.0 & 34.1 & 57.3 & 77.2 & 80.2 & 129.3 & 305.3 & 380.0 & 425.3 & 344.7 \\
\hline T8 & $160 \mathrm{~kg}$ ha-1 $\mathrm{N}$ in 4 equal splits of $25 \%$ each at sowing, 20,40 and $60 \mathrm{DAS}$ & 22.9 & 36.4 & 61.5 & 83.1 & 84.9 & 128.0 & 344.0 & 424.0 & 458.6 & 381.3 \\
\hline T9 & $\begin{array}{c}160 \mathrm{~kg} \text { ha- } 1 \mathrm{~N} \text { in } 4 \text { splits of } 10 \% \text { at sowing, } 10 \% \text { at } 20 \mathrm{DAS}, 40 \% \text { at } 40 \mathrm{DAS} \text { and } 40 \% \text { at } 60 \\
\text { DAS }\end{array}$ & 20.0 & 33.0 & 59.6 & 78.2 & 82.0 & 129.3 & 294.6 & 396.0 & 428.0 & 344.0 \\
\hline T10 & $\begin{array}{l}160 \mathrm{~kg} \text { ha- } 1 \mathrm{~N} \text { in } 4 \text { splits of } 20 \% \text { at sowing, } 20 \text { at } 20 \mathrm{DAS}, 30 \% \text { at } 40 \mathrm{DAS} \text { and } 30 \% \text { at } 60 \\
\text { DAS }\end{array}$ & 22.1 & 35.1 & 60.0 & 81.1 & 83.5 & 130.6 & 333.3 & 410.0 & 437.3 & 3362.0 \\
\hline & $\mathrm{SE}(\mathrm{m}) \pm$ & 0.8 & 1.4 & 2.4 & 2.9 & 2.9 & 5.7 & 13.7 & 18.1 & 18.1 & 15.9 \\
\hline & $\mathrm{CD}(\mathrm{p}=0.05)$ & NS & 4.0 & 7.2 & 8.7 & 8.7 & NS & 41.1 & 54.3 & 54 & 47.4 \\
\hline & $\mathrm{CV}(\%)$ & 6.8 & 7.0 & 7.4 & 6.5 & 6.4 & 7.7 & 7.8 & 8.3 & 7.5 & 8.1 \\
\hline
\end{tabular}

\section{Leaf Area Index (LAI)}

Leaf area index is an important trait that is related to canopy photosynthetic rate and dry matter production during crop growth period. An evaluation of LAI may enable us to quantify the growth and explore the factors that limit the dry

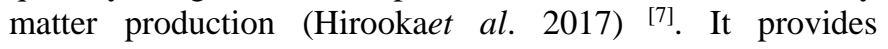

information on crop growth dynamics and is highly correlated with crop biomass and productivity (Venkateswarluet al. 1976) ${ }^{[11]}$. In this study leaf area index was estimated at 20 DAS, 40 DAS, 60 DAS, 80 DAS and harvest (Table 3). The green leaves were detached from the stem and area was 
measured by automatic leaf area meter. The total leaf area of the sample was estimated by following formula.

$$
\mathrm{LAI}=\frac{\text { Leaf area }}{\text { Unit ground area }}
$$

At 20 DAS, highest leaf area index (0.44) was recorded with application of nitrogen @ $160 \mathrm{~kg}$ ha- 1 in 4 equal splits of $25 \%$ each at sowing, 20, 40 and 60 DAS (T8) compared to the other treatments. However, this was found to be on par with the other lower doses of nitrogen viz., 120 and $140 \mathrm{~kg} \mathrm{~N}$ ha-1 applied in different splits. Lowest leaf area index was observed in the T3 - application of $120 \mathrm{~kg} \mathrm{~N}$ ha-1 in $10 \%$ at sowing, $10 \%$ at 20 DAS, $40 \%$ at 40 DAS and $40 \%$ at 60 DAS was shown on par with other doses and time of application of nitrogen in various splits.

At 40 DAS, same treatment (T8 - application of nitrogen @ $160 \mathrm{~kg}$ ha- 1 in 4 equal splits of $25 \%$ each at sowing, 20, 40 and 60 DAS) had continued to show the highest leaf area index (1.85) which was found to be on par with all the higher doses all the doses 140 and $160 \mathrm{~kg} \mathrm{~N}$ ha-1) of fertilizers applied in different splits, T2- application of nitrogen @ 120 $\mathrm{kg}$ ha- 1 in 4 equal splits of 25\% each at sowing, 20, 40 and 60
DAS and T4-120 kg N ha-1 in 4 splits of $20 \%$ at sowing, $20 \%$ at $20 \mathrm{DAS}, 30 \%$ at $40 \mathrm{DAS}$ and $30 \%$ at 60 DAS. Farmer's practice (T1- application of nitrogen at $120 \mathrm{~kg}$ ha- $1 \mathrm{~N}$ in 3 splits with $12 \%$ at sowing, $44 \%$ at 40 DAS and $44 \%$ at 60 DAS) recorded the lowest LAI (1.43) compared to the other treatments. However it was found to be significantly inferior to all the doses $(120,140$ and $160 \mathrm{~kg} \mathrm{~N}$ ha-1) when applied $25 \%$ each in 4 equal splits of at sowing, 20, 40 and 60 DAS (T2, T5, and T8), all the doses (120, 140 and $160 \mathrm{~kg} \mathrm{~N}$ ha-1) applied as $20 \%$ at sowing, $20 \%$ at 20 DAS, $30 \%$ at 40 DAS and $30 \%$ at $60 \mathrm{DAS}(\mathrm{T} 4, \mathrm{~T} 7$ and T10) and T9 - application of $160 \mathrm{~kg} \mathrm{~N}$ ha- 1 in $10 \%$ at sowing, $10 \%$ at $20 \mathrm{DAS}, 40 \%$ at 40 DAS and $40 \%$ at 60 DAS.

At 60 DAS, 80 DAS and harvest also application of nitrogen (a) $160 \mathrm{~kg}$ ha-1 in 4 equal splits of $25 \%$ each at sowing, 20, 40 and 60 DAS (T8) continued to register the highest leaf area index $(3.84,3.63$ and 1.75). The trend was similar to that of 40 DAS and farmer's practice (T1) continued to show the lowest leaf area index $(2.99,2.85$ and 1.30). Similar results were found by Amrutha (2014) ${ }^{[2]}$ and Hebbal (2015) ${ }^{[6]}$ in aerobic rice.

Table 3: Leaf area index and Dry matter production of semi dry rice as influenced by dose and time of nitrogen application

\begin{tabular}{|c|c|c|c|c|c|c|c|c|c|c|c|}
\hline \multirow[b]{2}{*}{$\begin{array}{l}\text { Trt. } \\
\text { No }\end{array}$} & \multirow[b]{2}{*}{ Treatment } & \multicolumn{5}{|c|}{ Leaf Area Index (LAI) } & \multicolumn{5}{|c|}{ Dry matter production (kg ha-1) } \\
\hline & & \begin{tabular}{c|c|c}
20 \\
DAS
\end{tabular} & \begin{tabular}{|c|}
40 \\
DAS \\
\end{tabular} & \begin{tabular}{c|c|}
60 \\
DAS
\end{tabular} & $\begin{array}{c}\text { 80 } \\
\text { DAS }\end{array}$ & Harvest & $\begin{array}{c}20 \\
\text { DAS }\end{array}$ & $\begin{array}{c}40 \\
\text { DAS }\end{array}$ & $\begin{array}{c}\text { 60 } \\
\text { DAS }\end{array}$ & $\begin{array}{c}\text { 80 } \\
\text { DAS }\end{array}$ & Harvest \\
\hline $\mathrm{T} 1$ & $\begin{array}{l}\text { Farmer's practice (120 kg ha- } 1 \mathrm{~N} \text { in } 3 \text { splits of } 12 \% \text { at sowing, } 44 \% \text { at } 40 \text { DAS } \\
\text { and } 44 \% \text { at } 60 \text { DAS) }\end{array}$ & 0.38 & .43 & 2.99 & 2.85 & 1.30 & 84 & 1337 & 3782 & 6535 & 8720 \\
\hline $\mathrm{T} 2$ & $120 \mathrm{~kg}$ ha- $1 \mathrm{~N}$ in 4 equal splits of $25 \%$ each at sowing, 20,40 and 60 DAS & 0.41 & 1.75 & 3.55 & 3.34 & 1.57 & 325 & 1599 & 4380 & 7422 & 9918 \\
\hline $\mathrm{T} 3$ & $\begin{array}{c}120 \mathrm{~kg} \text { ha- } 1 \mathrm{~N} \text { in } 4 \text { splits of } 10 \% \text { at sowing, } 10 \% \text { at } 20 \mathrm{DAS}, 40 \% \text { at } 40 \mathrm{DAS} \text { and } \\
40 \% \text { at } 60 \text { DAS. }\end{array}$ & 0.38 & 1.50 & 3.09 & 3.04 & 1.33 & 277 & 1409 & 4066 & 6873 & 9272 \\
\hline $\mathrm{T} 4$ & $\begin{array}{c}120 \mathrm{~kg} \text { ha- } 1 \mathrm{~N} \text { in } 4 \text { splits of } 20 \% \text { at sowing, } 20 \% \text { at } 20 \mathrm{DAS}, 30 \% \text { at } 40 \mathrm{DAS} \text { and } \\
30 \% \text { at } 60 \mathrm{DAS}\end{array}$ & 0.39 & 1.69 & 3.23 & 3.19 & 1.45 & 313 & 1507 & 4227 & 7162 & 9393 \\
\hline T5 & $140 \mathrm{~kg}$ ha- $1 \mathrm{~N}$ in 4 equal splits of $25 \%$ each at sowing, 20,40 and $60 \mathrm{DAS}$ & 0.42 & 1.80 & 3.71 & 3.43 & 1.68 & 333 & 1660 & 4570 & 7624 & 10401 \\
\hline T6 & $\begin{array}{c}140 \mathrm{~kg} \text { ha- } 1 \mathrm{~N} \text { in } 4 \text { splits of } 10 \% \text { at sowing, } 10 \% \text { at } 20 \mathrm{DAS}, 40 \% \text { at } 40 \mathrm{DAS} \text { and } \\
40 \% \text { at } 60 \mathrm{DAS}\end{array}$ & 0.39 & 1.65 & 3.37 & 3.27 & 1.55 & 280 & 1460 & 4382 & 7341 & 10130 \\
\hline $\mathrm{T} 7$ & $\begin{array}{c}140 \mathrm{~kg} \text { ha- } 1 \mathrm{~N} \text { in } 4 \text { splits of } 20 \% \text { at sowing, } 20 \% \text { at } 20 \mathrm{DAS}, 30 \% \text { at } 40 \mathrm{DAS} \text { and } \\
30 \% \text { at } 60 \mathrm{DAS}\end{array}$ & 0.41 & 1.73 & 3.54 & 3.32 & 1.56 & 317 & 1558 & 4499 & 7466 & 10236 \\
\hline T8 & $160 \mathrm{~kg}$ ha- $1 \mathrm{~N}$ in 4 equal splits of $25 \%$ each at sowing, 20,40 and $60 \mathrm{DAS}$ & 0.44 & 1.85 & 3.84 & 3.63 & 1.75 & 348 & 1772 & 4818 & 7984 & 10725 \\
\hline T9 & $\begin{array}{c}160 \mathrm{~kg} \text { ha- } 1 \mathrm{~N} \text { in } 4 \text { splits of } 10 \% \text { at sowing, } 10 \% \text { at } 20 \mathrm{DAS}, 40 \% \text { at } 40 \text { DAS and } \\
40 \% \text { at } 60 \mathrm{DAS}\end{array}$ & 0.40 & 1.68 & 3.53 & 3.37 & 1.59 & 307 & 1474 & 4568 & 7794 & 10318 \\
\hline T10 & $\begin{array}{c}160 \mathrm{~kg} \text { ha- } 1 \mathrm{~N} \text { in } 4 \text { splits of } 20 \% \text { at sowing, } 20 \text { at } 20 \mathrm{DAS}, 30 \% \text { at } 40 \text { DAS and } \\
30 \% \text { at } 60 \text { DAS }\end{array}$ & 0.41 & 1.79 & 3.66 & 3.49 & 1.64 & 327 & 1635 & 4673 & 7870 & 10574 \\
\hline & $\mathrm{SE}(\mathrm{m}) \pm$ & 0.03 & 0.08 & 0.14 & 0.13 & 0.08 & 22.7 & 75.6 & 186.0 & 262.6 & 398.1 \\
\hline & $\mathrm{CD}(\mathrm{p}=0.05)$ & $\mathrm{NS}$ & 0.23 & 0.41 & 0.40 & 0.23 & NS & 226.4 & 557.0 & 780.2 & 1189.8 \\
\hline & $\mathrm{CV}(\%)$ & 9.50 & 7.93 & 6.77 & 7.03 & 8.63 & 12.6 & 8.5 & 7.3 & 6.1 & 7.0 \\
\hline
\end{tabular}

\section{Dry matter production (kg ha-1)}

Photosynthesis is the foundation of dry matter production in plants. In rice, $90 \%$ of grain yield originates from the photosynthetic production of leaves after heading, especially from flag leaf. Production of adequate quantity of dry matter is essential for higher grain yield. Positive significant correlation was reported in dry matter production with grain yield. Dry matter production is also an important plant growth parameter in defining grain harvest index which is a ratio of grain yield to total biological yield (Fageria, 2004) ${ }^{[4]}$. Dry matter accumulation by semi dry rice at 20 DAS, 40 DAS, 60 DAS, 80 DAS and harvest is presented in table 3.

At 20 DAS, highest dry matter (348 kg ha-1) was recorded with application of nitrogen @ $160 \mathrm{~kg}$ ha-1 in 4 equal splits of $25 \%$ each at sowing, 20, 40 and 60 DAS compared to the other treatments. However, this was found to be on par with the other lower doses of nitrogen viz., 120 and $140 \mathrm{~kg} \mathrm{~N}$ ha1applied at various splits. Lowest dry matter (277 kg ha-1) was produced in the treatment (T3- application of $120 \mathrm{~kg} \mathrm{~N}$ ha- 1 with $10 \%$ at sowing, $10 \%$ at 20 DAS, $40 \%$ at 40 DAS and $40 \%$ at $60 \mathrm{DAS}$ ). They were found to be on par with all the doses and split application of 140 and $160 \mathrm{~kg} \mathrm{~N}$ ha-1.

At 40 DAS, similar trend continued with treatment T8 (160 $\mathrm{kg} \mathrm{N}$ ha-1 in 4 equal splits) being the highest in dry matter production (1772 kg ha-1) compared to the other treatments. It was found to be on par with application of different doses of 120 and $140 \mathrm{~kg} \mathrm{~N}$ ha-1 when they were applied in four equal splits of $25 \%$ each at sowing, 20, 40 and 60 DAS (T2 and T5) and other treatments like T10-160 kg N ha-1 in 4 splits of $20 \%$ at sowing, $20 \%$ at 20 DAS, $30 \%$ at 40 DAS and $30 \%$ at 60 DAS and T7-140 kg N ha- 1 in 4 splits of $20 \%$ at sowing, $20 \%$ at $20 \mathrm{DAS}, 30 \%$ at $40 \mathrm{DAS}$ and $30 \%$ at $60 \mathrm{DAS}$. Farmer's practice recorded the lowest dry matter production (1337 kg ha-1) and was significantly inferior than the all the doses (120, 140 and $160 \mathrm{~kg} \mathrm{~N}$ ha-1) when applied $25 \%$ each in 4 equal splits of at sowing, 20, 40 and 60 DAS (T2, T5, and T8) and T10 - $160 \mathrm{~kg} \mathrm{~N}$ ha-1 in 4 splits of $20 \%$ at sowing, $20 \%$ at $20 \mathrm{DAS}, 30 \%$ at $40 \mathrm{DAS}$ and $30 \%$ at $60 \mathrm{DAS}$. 
At 60 DAS, 80 DAS and at harvest also application of nitrogen @ 160 kg ha-1 in 4 equal splits i.e., at sowing, 20, 40 and 60 DAS continued to show the highest dry matter production of $4818 \mathrm{~kg}$ ha-1, $7984 \mathrm{~kg}$ ha-1 and $10725 \mathrm{~kg}$ ha-1 respectively which was on par with the treatments having 160 and $140 \mathrm{~kg} \mathrm{~N}$ ha-1 applied at various splits and $\mathrm{T} 2$ (application of $120 \mathrm{~kg} \mathrm{~N}$ ha-1 $\mathrm{N}$ in 4 equal splits at sowing, 20, 40 and 60 DAS). Lowest dry matter (3782 kg ha-1, 6535 kg ha- 1 and $8720 \mathrm{~kg}$ ha-1) was registered in farmer's practice at 60 DAS, 80 DAS and at harvest respectively which was significantly inferior to the treatments with 140 and $160 \mathrm{~kg} \mathrm{~N}$ ha-1 and application of $120 \mathrm{~kg} \mathrm{~N}$ ha-1 in 4 equal splits at sowing, 20, 40 and 60 DAS. Similar results were found by Hebbal (2015) ${ }^{[6]}$ in aerobic rice and Bai et al. (2014) ${ }^{[3]}$ in semi dry rice.

\section{Conclusion}

Application $120 \mathrm{~kg}$ nitrogen in 4 equal splits of $25 \%$ each at sowing, 20, 40 and 60 DAS was found to be the most appropriate dose and time of application for semidry rice on clay loams of Telangana.

\section{References}

1. Agricultural statistics. Directorate of Economics and Statistics. Government of India. New Delhi, 2016.

2. Amrutha TG. Studies on levels and time of application of nitrogen on performance of rice under aerobic condition. MSC (Ag) Thesis. University of Agricultural Sciences, Bangalore, India, 2014.

3. Bai, JK, Murthy RKV, Naidu VM, Uma Mahesh V. Performance of semi-dry rice as affected by graded levels and time of application of nitrogen. The Andhra Agricultural Journal. 2014; 61(1):44-48.

4. Fageria NK. Dry matter yield and nutrient uptake by lowland rice at different growth stages. Journal of Plant Nutrition. 2004; 27(6):947-958.

5. FAO (2016). http://www.fao.org/faostat/en/\#home

6. Hebbal N. Effect of nitrogen levels and time of application on productivity of aerobic rice. M.Sc. (Ag.) Thesis. University of Agricultural Science, Banglore, India, 2015.

7. Hirooka Y, Homma K, Maki M, Sekiguchi K, Shiraiwa T, Yoshida K. Evaluation of dynamics of leaf area index of rice in farmers' fields in Vientiane provice, Lao PDR. Journal of Agricultural Meteorology. 2017; 73(1):16-21.

8. Miller BC, Hil JE, Roberts SR. Plant population effects on growth and tied in water seeded rice. Agronomy Journal. 1991; 83:291-297.

9. Rani SK. Influence of nitrogen and weed management on growth and yield of aerobic rice. M.Sc. (Ag.) Thesis. Acharya N.G. Ranga Agricultural University, Hyderabad. Season and crop report Telangana, 2016-17. Directorate of Economics and Statistics Government of Telangana. Hyderabad, 2012.

10. Thind HK, Singh Y, Sharma S, Goyal D, Singh Vand Singh B et al. Optimal rate and schedule of nitrogen fertilizer application for enhanced yield and nitrogen use efficiency in dry-seeded rice in north-western India. Archives of Agronomy and Soil Science. 2018; 64(2):196-207.

11. Venkateswarlu B, Rao PK, Rao AV. Canopy analysis on the relationships between leaf area index and productivity in lowland rice. Plant and Soil. 1976; (45):49-56. 